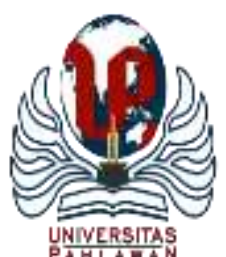

\title{
JURNALBASICEDU
}

Volume 5 Nomor 6 Tahun 2021 Halaman 5050-5057

Research \&Learningin Elementary Education

https://jbasic.org/index.php/basicedu

\section{Implikasi Model Pembelajaran VCT (Value Clarification Technique) dalam Meningkatkan Kesadaran Nilai Moral pada Pembelajaran PKn di SD}

\author{
Farah Sabilla Febriany $^{1 \bowtie}$, Hani Risdiany ${ }^{2}$, Dinie Anggraeni Dewi ${ }^{3}$, Yayang Furi Furnamasari ${ }^{4}$ \\ Pendidikan Guru Sekolah Dasar, Universitas Pendidikan Indonesia, Indonesia ${ }^{1,2,3,4}$

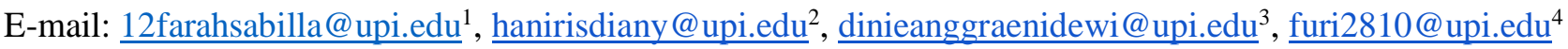

\begin{abstract}
Abstrak
Bagi siswa untuk belajar bagaimana menjadi siswa yang baik menjadikan sebagai warga negara, mereka perlu mengklarifikasi kesadaran nilai moral. Namun istilah siswa yang baik menimbulkan interpretasi dan definisi yang berbeda dalam sistem yang berbeda. Sasaran subjek penulis ini adalah siswa sekolah dasar yang menjadi dasar penanaman nilai moral sejak jenjang dini dan meningkatkan kesadaran nilai moral menjadi hal utama. Penelitian ini bertujuan mengeksplorasi implikasi model pembelajaran VCT dalam meningkatkan kesadaran moral terhadap pembelajaran di SD. Metode yang digunakan dalam permasalahan studi komprehensif yaitu menggunakan pendekatan kualitatif. Pengumpulan data yang digunakan adalah tinjauan pustaka untuk pengkajian studi literatur. Proses pengolahan data yang telah didapatkan akan dikompilasi, analisis, simpulan, dan hasil kesimpulan akhir mengenai studi literatur. Analisis hasil yang didapatkan yaitu mengidentifikasi model VCT, motivasi untuk meningkatkan kesadaran nilai moral, serta penerapan dari model VCT di mata pelajaran PKn jenjang sekolah dasar. Pembelajaran PKn (pendidikan kewarganegaraan) menjadi bidang dimana siswa secara khusus disebut sebagai wadah untuk membantu siswa dalam klarifikasi nilai moral.
\end{abstract}

Kata Kunci: Model Value Clarifications Technique (VCT), Nilai moral, PKn.

\begin{abstract}
For students to learn how to be good students to become citizens, they need to clarify their awareness of moral values. However, the term good student country gives rise to different interpretations and definitions in different systems. The target subject of this writer is elementary school students who are the basis for inculcating moral values from an early stage and increasing awareness of moral values is the main thing. This study aims to explore the implications of the VCT learning model in increasing awareness of moral values in learning in elementary schools. The method used in the problem of a comprehensive study is using a qualitative approach. The data collection used is a literature review for the study of literature. The data processing process that has been obtained will be compiled, analyzed, concluded, and the final conclusions regarding the study of literature. The analysis of the results obtained is to identify the VCT model, the motivation to increase awareness of moral values, and the application of the VCT model in PKn subjects at the elementary school level. PKn learning is a field where students are specifically referred to as a forum to assist students in clarifying moral values.
\end{abstract}

Keywords:Value Clarifications Technique (VCT) Model, moral value, PKn.

Copyright (c) 2021 Farah Sabilla Febriany, Hani Risdiany, Dinie Anggraeni Dewi, Yayang Furi Furnamasari

$\triangle$ Corresponding author :

Email: 12 farahsabilla@upi.edu

DOI $\quad$ : https://doi.org/10.31004/basicedu.v5i6.1589

ISSN 2580-3735 (Media Cetak)

ISSN 2580-1147 (Media Online) 
5051 Implikasi Model Pembelajaran VCT (Value Clarification Technique) dalam Meningkatkan Kesadaran Nilai Moral pada Pembelajaran PKn di SD - Farah Sabilla Febriany, Hani Risdiany, Dinie Anggraeni Dewi, Yayang Furi Furnamasari

DOI : https://doi.org/10.31004/basicedu.v5i6.1589

\section{PENDAHULUAN}

Sistem sekolah dasar telah digunakan sebagai kendaraan untuk melaksanakan agenda sosial atau politik, dan menjadi tujuan pertama pendidikan di sekolah adalah mengembangkan dan menggali potensi peserta didik menjadi penerus warga negara yang baik, yang dapat mampu bermasyarakat dan beradaptasi dalam berperan sebagai manusia bersosialisasi dalam kehidupan yang layak. Namun, definisi warga negara yang baik bermacam-macam dari satu negara ke negara lainnya, atau bahkan dalam satu negara (Bee Piang Tan, Noor Banu Mahadir Naidu, 2018). Nilai menjadi warga negara adalah salah satu faktor kunci dalam memahami mengapa definisi warga negara yang baik menimbulkan interpretasi yang berbeda. Nilai mengacu pada prinsip dan keyakinan yang berfungsi sebagai pedoman umum untuk perilaku, standar yang dengannya tindakan tertentu dianggap baik atau diinginkan. Contoh nilai-nilai adalah kasih sayang, kedudukan yang setara, freedom, adil, bahagia, rasa aman, rasa tenang jiwa, dan suatu kebenaran.

Seorang siswa yang percaya pada nilai tanggung jawab dapat terus menjadi masyarakat yang mematuhi hukum dan sesuai pada niat pembuat kebijakan. Hal ini dapat dianggap sebagai warga negara yang baik. Semua negara, tanpa terkait dari ideologi politiknya, baik secara eksplisit maupun implisit ingin mendidik rakyatnya menjadi siswa sebagai warga yang bermoral, yang selaras dengan nilai-nilai negara. Sebagai negara multi kultural dan multi agama, Indonesia terus berjuang dengan tantangan pembangunan bangsa melalui generasi muda ini diberikan pendidikan moral sejak sedini mungkin pendidikan digunakan sebagai sarana untuk mempromosikan identitas nasional dan kohesi sosial dalam persatuan nasional (Mayasari, 2018). Tujuan utama dari sistem pendidikan (Cokelat, 2007). Memahami tujuan peningkatan bersosial, berbagai lembaga pendidikan mengupayakan pengembangan kurikulum untuk mempersiapkan siswa terjun ke dalam masyarakat menjadi generasi muda yang bermoral yang berawal dari pelajaran PKn. Pendidikan kewarganegaraan adalah elemen penting sebagai penerapan nilai-nilai moral misalnya prinsip-prinsip kesetaraan, keadilan, kebebasan, hak, menghormati perbedaan, tugas dan tanggung jawab, transparansi, solidaritas dan lain-lain (Riza, 2021). Untuk membangun siswa sekolah dasar memiliki nilai moral yang baik maka pendidikan perlu memperhitungkan metode-metode dalam menanamkan dan meningkatkan dalam kesadaran nilai moral di dalam pelajaran PKn (Pratomo n.d.).

Dilihat dari penelitian para peneliti sebelumnya, permasalahan yang ditemukan di lembaga pendidikan adalah kurangnya pengajar yang menggunakan metode pembelajaran yang sesuai, metode pengajar dan media pembelajaran sangat berpengaruh terhadap kegiatan dan respon siswa. Model pembelajaran juga sangat membantu pengajar pada materi pembelajaran. Menentukan model dan metode pembelajaran yang tepat dapat menjadikan siswa lebih bersemangat, aktif, dan tidak mudah bosan, serta hasil belajar siswa akan meningkat.

Menurut (Agustin, N., \& Hamid 2017) dengan judul "Pengaruh Model Pembelajaran VCT terhadap Penalaran Moral Siswa dalam Pembelajaran PKn SD" Hasil penelitian tersebut menampilkan bahwa pembelajaran model VCT berpengaruh signifikan kepada keterampilan berpikir perilaku siswa pada pembelajaran kewarganegaraan dibandingkan pembelajaran kewarganegaraan menggunakan metode konvensional yakni $0,000<0,05$. Dalam perhitungan tersebut dapat diketahui bahwa dampak positif model VCT merupakan salah satu metode dalam meningkatkan karakter atau perilaku moral siswa dalam belajar.

Adapun pengkajian (Rodiyana 2019) yang berjudul "Penerapan Metode Pembelajaran VCT dalam mengembangkan perilaku Demokratis peserta didik pada Pembelajaran PKn di SD” dalam pandangan persentase siklusnya yaitu siklus $1=54,45 \%$, siklus $2=65,76 \%$, siklus $3=78,40 \%$, dan siklus $4=85,23 \%$. Hal tersebut bisa menjadikan bukti bahwa penerapan model VCT bisa meningkatkan perilaku demokratis peserta didik di kelas V Sekolah Dasar Negeri Majalengka Kulon I, Sekolah Dasar Negeri Tarikolot I, Sekolah Dasar Negeri Tarikolot II, serta Sekolah Dasar Negeri Cikasarung. Sedemikian rupa sehingga mengarah pada kenyataan bahwa siswa menjadi lebih aktif dan mengetahui karakter yang baik atau nilai-nilai yang baik 
5052 Implikasi Model Pembelajaran VCT (Value Clarification Technique) dalam Meningkatkan Kesadaran Nilai Moral pada Pembelajaran PKn di SD - Farah Sabilla Febriany, Hani Risdiany, Dinie Anggraeni Dewi, Yayang Furi Furnamasari

DOI : https://doi.org/10.31004/basicedu.v5i6.1589

dalam diri mereka sendiri, sehingga karakter tersebut berubah seiring bertambahnya ilusi untuk belajar, rasa percaya diri yang tinggi dan simpati dengan siswa, teman juga. meningkatkan.

Dari persoalan tersebut, salah satu metode pengkajian yang peneliti tersebut pilih adalah menumbuhkan kesadaran tentang nilai-nilai moral pada siswa sekolah dasar (SD) melalui mata pelajaran pendidikan kewarganegaraan adalah metode VCT. Model pembelajaran VCT (Taniredja, T.\& Harimanto, 2015) yaitu model dalam membantu peserta didik dalam mewujudkan keputusan dari nilai yang baik dalam menanggapi masalah sesuai analisa nilai-nilai yang telah terkandung sejak lama sesuai ideologi negara. Teknik VCT ini digunakan dalam pembelajaran PKn untuk memotivasi dan mendukung siswa dalam menganalisa permasalahan yang meningkatkan kesadaran nilai sosial. Bertepatan pada penelitian sebelumnya dengan penelitian yang penulis lakukan adalah dengan menggunakan VCT sebagai metode pembelajaran. Perbedaan dalam penelitian ini terletak pada tempat, tempat dan waktu penelitian. Selanjutnya, metode penelitian dan bahan yang digunakan penulis juga berbeda dengan penelitian sebelumnya.

Tujuan dari pengkajian merupakan untuk mengukur kesadaran peserta didik terhadap suatu nilai yang kemudian bergerak ke arah yang lebih baik, memotivasi peserta didik untuk meningkatkan kesadaran nilai moral, serta mengetahui implikasi dari model VCT di mata pelajaran PKn jenjang sekolah dasar.

Diharapkan penelitian ini dapat dijadikan acuan dalam menunjang para guru saat upaya mengembangkan nilai moral anak didik tersebut. dalam pembelajaran dengan pendekatan VCT, siswa memperoleh orientasi dan menanamkan dalam suatu nilai sehingga nilai tersebut mengutamakan seperti disiplin, tanggung jawab, sopan santun, kejujuran, keadilan, dan banyak sikap baik lainnya dapat diterapkan setiap hari. Model VCT adalah pilihan dalam pendidik untuk memberikan pengajaran postur selama kelas. Dalam memakai model VCT diperlukan bisa memberikan pengalaman dari proses belajar di berbagai kehidupan bermasyarakat seperti siswa mampu menangkal permasalahan, mengabaikan sesuatu yang dianggap negatif, mengintervensi dan mengintegrasikan berbagai nilai moral, serta berakhlak mulia dalam kehidupan masyarakat yang layak.

\section{METODE PENELITIAN}

Penelitian berikut dilaksanakan berdasarkan metode kualitatif serta pendekatan studi pustaka. Studi kepustakaan dilakukan dengan bersumber pada berbagai macam literatur diantaranya seperti buku, tesis, artikel, serta jurnal daring. Metode tersebut bisa mencakup uraian data hasil pengamatan pada berbagai tulisan ataupun karya individu-individu dalam riset terdahulu.

Dengan menerapkan metode kualitatif, penelitian berikut lebih berfokus pada analisa atas beragam sumber pustaka yang sudah terkumpul, data dalam riset terdahulu yang sudah pernah dilaksanakan, teori, sekaligus definisi yang selaras dengan topik penelitian yang sedang dibahas, dan sumber lainnya yang mengarah pada fokus pembahasan utama dalam penelitian. Tahapan yang diambil yakni mengerucutkan sejumlah data, kemudian menyajikannya, serta mengambil kesimpulan.

\section{HASIL DAN PEMBAHASAN}

\section{Pendidikan dan Penanaman Moral di Sekolah Dasar}

Pendidikan kewarganegaraan adalah pelajaran yang dapat menanamkan apa itu pendidikan perilaku moral dan tanggung jawab dalam memastikan bahwa seseorang memiliki moral yang baik dan menjadi manusia. Pendidikan akhlak merupakan langkah-langkah, pendekatan yang digunakan bersifat komprehensif, pendidikan ini harus dilaksanakan secara pemberdayaan di sekolah, rumah dan masyarakat, dengan melibatkan seluruh pemangku kepentingan dan masyarakat. Menurut (Wuryandani 2010) keberadaan 
5053 Implikasi Model Pembelajaran VCT (Value Clarification Technique) dalam Meningkatkan Kesadaran Nilai Moral pada Pembelajaran PKn di SD - Farah Sabilla Febriany, Hani Risdiany, Dinie Anggraeni Dewi, Yayang Furi Furnamasari

DOI : https://doi.org/10.31004/basicedu.v5i6.1589

pendidikan akhlak bukan sia-sia. Tujuan pendidikan moral adalah sebagai berikut: (1) Mempromosikan dan mengajarkan nilai dan norma moral. (2) Mengembangkan kualitas diri, kelompok, atau kehidupan manusia. (3) Pertahanan, minimalisasi dan eliminasi hal-hal negatif. Pendidikan moral untuk peserta didik sekolah dasar harus mampu mengubah moral anak sedemikian rupa sehingga mereka memikul tanggung jawab dan saling menghormati di masa dewasa serta bisa menjalankan situasi zaman yang berubah dengan cepat, maka dari itu sangat penting perilaku moral yang berfungsi dalam media transformasi kepada negara ini menjadi lebih baik dengan mempunyai keistimewaan dan kecerdasan di beberapa bidang; baik kecerdasan emosional, kecerdasan sosial, kecerdasan spiritual, kecerdasan kinestetik, kecerdasan logis, musikal, linguistik, serta kecerdasan spasial (Habibah 2007).

Berikut ini adalah nilai-nilai akhlak dan budi pekerti yang akan diajarkan di sekolah dasar dan harus menanamkan akhlak di SD (Suparno 2002), antara lain: (1) Religiusitas. Saat mengajarkan nilai-nilai agama di sekolah dasar, kebiasaan shalat yang sudah diajarkan sejak TK harus tetap dipertahankan. dengan kegiatan doa, sebelum melakukan kegiatan apapun, siswa membiasakan diri dan memperkenalkan diri dengan adanya suatu kekuatan yang melampaui manusia dan bahwa segala sesuatu ada pada sang pencipta. (2) Bersosialisasi. Kegiatan dan kegiatan kelompok dapat mengenalkan anak dalam sikap saling menghargai, saling membantu, peduli, dan saling menghargai. (3) Jenis kelamin. Perempuan dan laki-laki mungkin berbeda berdasarkan jenis kelamin, tetapi tidak ada perbedaan dalam hal peran gender, kemampuan individu lah yang membuat perbedaan. Dengan itu, kesamaan gender harus ajarkan sejak kecil dan dari tatanan terkecil yaitu keluarga, masyarakat dan sekolah. (4) Keadilan. Memperlakukan dan menjamin persamaan serta hak dan kewajiban antara perbedaan gender adalah elemen dari pendidikan peradilan anak. (5) Demokrasi. Nilai demokrasi bisa dikembangkan dengan baik dan tepat; Sikap demokratis berarti mengakui keragaman dan perbedaan satu sama lain. Beberapa contohnya adalah pemilihan ketua kelas, pemilihan tim pramuka, atau kegiatan lainnya. (6) Jujur. perilaku dan prinsip kejujuran yang diajarkan kepada siswa pada tingkat dasar. Dalam konteks ini, peran guru dalam mengamati dengan koreksi sangat penting, guru dapat menilai apakah siswa jujur atau tidak dari coretan siswa. (7) Kemerdekaan. Kegiatan ekstrakurikuler adalah sarana yang tepat untuk memberdayakan peserta didik agar mandiri. Contohnya adalah ikut pramuka. Pramuka yang terencana dengan baik dapat membuat anak laki-laki lebih aktif, berolahraga, dan senang memecahkan masalah. (8) Kekuatan tempur. Daya juang anak dapat secara khusus dipromosikan dan dikembangkan melalui kegiatan olahraga. Kegiatan olahraga tidak hanya dapat mengembangkan kekuatan juang, tetapi juga dapat menjadi sarana untuk mengembangkan sikap jujur atau atletis. (9) Tanggung jawab. Penugasan piket yang diberikan kepada setiap anak secara bergiliran, dapat menjadi sarana untuk menanamkan tanggung jawab di dalam kelas. Kenyamanan dan kebersihan kelas bukan hanya tugas guru piket, tetapi juga tanggung jawab warga kelas demi kebaikan kelas itu sendiri. (10) Penghargaan terhadap lingkungan alam. Pengabdian kepada masyarakat melibatkan proses pembelajaran yang baik untuk mengenal lingkungan sekolah. Anak-anak tidak hanya membersihkan atau menyapu halaman sekolah, tetapi juga mengenal alam hijau yang indah sehingga mereka merasa lebih nyaman dan menjadi lebih sehat saat belajar di sekolah.

Terdapat beragam faktor yang bisa menjadi penyebab kemerosotan moral pada anak, antara lain seperti: (a) Materi Praktek Budi Pekerti yang kurang, (b) Mental Generasi Bangsa yang lemah, (c) Teknologi yang berkembang, (d) Budaya Barat yang tidak tersaring, (e) Konsep Moral yang disalahgunakan, (f) Sebagian ajaran moral yang disalah gunakan(Vitasari, 2015).

\section{Model Pembelajaran VCT}

Model pembelajaran VCT (Value Clarification Technique) dikembangkan oleh bidang teori konseling didesain guna membantu membina individu dalam membuat keputusan dalam pilihan hidup individu (Kirschenbaum 2013). Model pembelajaran VCT diperkenalkan pertama oleh Rats yaitu seorang guru di 
5054 Implikasi Model Pembelajaran VCT (Value Clarification Technique) dalam Meningkatkan Kesadaran Nilai Moral pada Pembelajaran PKn di SD - Farah Sabilla Febriany, Hani Risdiany, Dinie Anggraeni Dewi, Yayang Furi Furnamasari

DOI : https://doi.org/10.31004/basicedu.v5i6.1589

Amerika Serikat tahun 1950 dengan sebutan value clarification yang terus menerus dikembangkan oleh tokoh atau pendidik lainnya sehingga dikenal Value Clarification Technique (VCT). Ada banyak definisi yang berbeda dari model VCT dalam literatur adalah proses pengembangan berkelanjutan untuk mendefinisikan apa yang dihargai (apa yang diyakini paling penting dan paling diperhatikan), dan bagaimana seseorang bertindak berdasarkan nilai-nilai itu di kehidupan keseharian. Model VCT yaitu proses mendefinisikan nilai seseorang. Dengan memperjelas nilai-nilai diri yang membantu membimbing dalam aktivitas sehari-hari dan membantu menyelaraskan apa yang akan katakan dengan apa yang dilakukan. Setelah seseorang mengklarifikasi nilai-nilainya, mereka harus dapat dengan cepat menyebutkan nilai-nilai yang paling dianggap baik dan benar. Sedangkan definisi Kirschenbaum tentang model VCT adalah "suatu pendekatan yang menggunakan pertanyaan dan aktivitas yang dirancang untuk mengajarkan proses penilaian dan untuk membantu individu dengan terampil menerapkan proses penilaian pada area yang kaya nilai dalam kehidupan mereka" (Kirschenbaum 2013). Namun, Kirschenbaum tidak menegaskan bahwa model VCT akan menjadi satu-satunya jawaban model yang benar bagi individu, karena tidak memberikan semua jawaban. Namun, karya Kirschenbaum memang menjelaskan proses penilaian. Penulis mengemukakan jika orang terlibat dalam proses ini, hidup mereka akan memiliki nilai lebih positif dan mereka akan menjadi warga global yang konstruktif (Kirschenbaum 2013).

VCT menjadi sebuah model pembelajaran sikap dengan memfokuskannya pada upaya untuk menanamkan nilai-nilai lewat suatu proses dalam menganalisis nilai yang telah ada dalam diri peserta didik untuk setelahnya disesuaikan dan dipadukan dengan nilai baru yang hendak ditanam dalam diri peserta didik. Dalam (Adisusilo, 2013) Hall menjabarkan bahwa model VCT bisa membantu siswa supaya memiliki kemampuan maupun keterampilan dalam menetapkan berbagai nilai kehidupan yang sesuai dengan tujuan hidup yang dipilihnya. Lebih lanjut, Hall juga mengurai bahwa para peserta didik kemudian menginternalisasikan kemampuan dan keterampilan yang diperoleh tersebut sehingga mentransformasikan nilai untuk dijadikan pedoman dalam bersikap dan bertingkah laku. Di sisi lain, (Taniredja2012 ; 88) menyatakan bahwa tujuan digunakannya model VCT untuk pembelajaran yakni (1) Melakukan pengukuran dan mengetahui tingkat kesadaran peserta didik terkait sebuah nilai sehingga bisa menjadi dasar pijakan dalam menetapkan target yang hendak diraih. (2) Menerapkan penanaman kesadaran peserta didik mengenai berbagai nilai yang dipunya termasuk di sifat dan sikap yang positif dan negatif untuk kemudian ditanamkan demi meningkatkan dan mencapai nilai yang ditargetkan. (3) Membantu menanam berbagai nilai tertentu pada siswa melalui cara yang bisa didapat siswa dengan cara logis (rasional). Selanjutnya, diharapkan akhirnya nilai tersebut bisa dimiliki peserta didik bukan sebagai suatu kewajiban moral, melainkan sebagai proses kesadaran moral. (4) Memberi pelatihan peserta didik untuk menilai atau menerima diri sekaligus menyadari posisi nilai yang dimiliki oleh individu lainnya. Selain itu, melatih mereka dalam menerima dan membuat keputusan atas suatu permasalahan yang berkenaan dengan pergaulan dan kehidupan kesehariannya.

Berdasarkan pendapat yang sudah disebutkan, peneliti mengambil kesimpulan bahwa model VCT memiliki tujuan yakni guna mengidentifikasi dan melakukan pengukuran tingkat kesadaran peserta didik, membantu penanaman kesadaran pada peserta didik mengenai berbagai nilai, menerapkan penanaman nilainilai tertentu lewat cara yang logis, serta memberi pelatihan pada peserta didik supaya bisa membuat keputusan atas sebuah permasalahan. Oleh karena itu, peserta didik diharap bisa memiliki keterampilan untuk menetapkan berbagai nilai kehidupan yang sesuai dengan tujuan hidup yang dipilih dan nantinya menjadi pedomannya ketika bersikap dan bertingkah laku.

\section{Jenis-jenis Model Pembelajaran VCT}

Model pembelajaran VCT bisa digunakan dengan berbagai metode Kosasih (Solihatin, 2012) memberikan klasifikasi terhadap model pembelajaran VCT menjadi 3 bagian, yakni: (1) daftar, mencakup 
5055 Implikasi Model Pembelajaran VCT (Value Clarification Technique) dalam Meningkatkan Kesadaran Nilai Moral pada Pembelajaran PKn di SD - Farah Sabilla Febriany, Hani Risdiany, Dinie Anggraeni Dewi, Yayang Furi Furnamasari

DOI : https://doi.org/10.31004/basicedu.v5i6.1589

daftar gejala sikap pelakonan, daftar gejala kontinum, daftar skala sikap, daftar tingkat urutan, serta daftar baik dan buruk; (2) analisis, meliputi inquiry nilai, analisis nilai, tanya jawab nilai, teknik liputan, serta percontohan; dan (3) permainan, meliputi permainan menyimak dan mendengar orang lainnya, permainan kartu keyakinan, permainan jurnal harian dan bank data, permainan pecahan kartu segi empat, serta permainan pengandaian. Pernyataan serupa juga disebutkan oleh Djahiri (Komalisari 2010) yang melakukan pengembangan VCT dalam pembelajaran nilai, diantaranya dengan VCT permainan, VCT daftar nilai, serta VCT analisis nilai. Pemakaian tiap jenis VCT sangat ketergantungan dengan tujuan dari pembelian pengajaran dan materi yang hendak disampaikan. Penggunaannya juga bisa dilaksanakan baik secara terpisah maupun terpacu sebab diperlukan adanya penyesuaian dengan lingkungan tempat pelaksanaan pembelajarannya, tingkat kemampuan peserta didik, serta tingkat kesulitannya.

\section{Langkah-langkah Model Pembelajaran VCT}

Proses pembelajaran VCT pada umumnya meliputi tujuh aspek ataupun tahapan yang umumnya dikelompokkan ke dalam 3 tingkatan. Jarolimek (Tukiran dkk. Taniredja, 2012) menyatakan bahwa tujuh tahapan yang dibagi menjadi 3 tingkatan yang dimaksudkan meliputi: a. Pemilihan usah dilakukannya analisis pertimbangan konsekuensi yang hendak muncul menjadi akibat pilihan yang diambil. b. Pemilihan terhadap berbagai alternatif yang tersedia. c. Pemilihan bebas. Tingkatan 2. Menghargai dalam tingkatan ini mencakup dua tahapan pembelajaran, yakni: a. Penegasan nilai yang telah menjadi bagian intergram dalam diri di hadapan umum. b. Perasaan bangga dan senang dengan nilai yang sudah menjadi pilihan. Tingkat 3 . Berbuat pada tingkatan ini meliputi dua tahapan pembelajaran, yakni: a. Kemauan untuk mengulang sikap sesuai dengan nilai yang dipilih. b. Kemampuan serta kemauan dalam mempraktikkannya.

Di satu sisi, untuk model pembelajaran VCT, analisis nilai, diterapkan beberapa langkah dalam aktivitas pembelajaran menjadi: (1) Pendidik merangsang pembelajaran dengan menampilkan film, foto, dan gambar ataupun membacakan cerita. (2) Memberikan kesempatan selama beberapa waktu pada peserta didik supaya bisa berpikir ataupun melakukan dialog dengan teman sebaya berkaitan dengan rangsangan yang dimaksud. (3) Melakukan dialog terpimpin lewat pertanyaan dari guru, baik secara klasikal, kelompok, ataupun individu. (4) Menetapkan opini dan klarifikasi pendirian (lewat pertanyaan guru serta bersifat klasikal, kelompok, serta individual). (5) Pembuktian ataupun pembahasan opini. Dalam fase berikut, telah mulai ditanam konsep dan nilai yang ditargetkan sesuai dengan materi yang diajarkan. (6) Pengambilan kesimpulan.

\section{Kelebihan dan Kelemahan Model Pembelajaran VCT}

Djahiri (Tukiran dkk. Taniredja, 2012)menyebut bahwa model pembelajaran VCT mempunyai kelebihan pada pemberian pengajaran afektif, yakni: (1) Mampu memberi pembinaan serta penanaman modal serta nilai dalam ranah sisi internal. (2) Mampu melakukan penggalian atau pengklasifikasian serta pengungkapan isi pesan materi yang hendak diajarkan, kemudian bisa memberikan kemudahan untuk para pendidik dalam penyampaian moral, pesan nilai, ataupun makna. (3) Mampu melakukan pengklasifikasian serta memberikan penilaian mutu nilai modal diri peserta didik, mengobservasi nilai individu lainnya, serta melakukan pemahaman nilai moral yang terdapat pada kehidupan riil. (4) Mampu merangsang, melibatkan, melakukan pembinaan serta pengembangan potensi diri peserta didik khususnya pengembangan potensi sikap. (5) Mampu memberi sejumlah pengalaman belajar berdasarkan beragam pengalaman hidup. (6) Mampu melakukan penyangkalan, peniadaan, pengintervensian, serta memadukan beragam nilai moral pada sistem moral sekaligus nilai pada diri seorang individu. (7) Memberikan gambaran nilai moral yang patut diinternalisasi serta memotivasi dan menuntunnya dalam mendapat kehidupan yang memiliki moral tinggi dan layak. 
5056 Implikasi Model Pembelajaran VCT (Value Clarification Technique) dalam Meningkatkan Kesadaran Nilai Moral pada Pembelajaran PKn di SD - Farah Sabilla Febriany, Hani Risdiany, Dinie Anggraeni Dewi, Yayang Furi Furnamasari

DOI : https://doi.org/10.31004/basicedu.v5i6.1589

Di sisi lain, kekurangan dari penerapan model pembelajaran ini berdasarkan Taniredja (2012:91) yakni. (1) Jika pendidik tidak mempunyai kemampuan untuk melibatkan peserta didik dengan penuh kehangatan, saling pengertian, serta keterbukaan, peserta didik bisa memperlihatkan sikap palsu ataupun semu. Peserta didik bisa bersikap sebagai peserta didik yang penurut, patuh, ideal, dan baik tetapi hanya demi membuat pendidik senang ataupun demi mendapat nilai bagus. (2) Sistem penilaian yang dipunya dan ditanamkan pada masyarakat, peserta didik, dan pendidik yang tidak baku ataupun kurang bisa memicu gangguan untuk mencapai nilai yang ditargetkan. (3) Sangat bergantung pada keterampilan pendidik dalam memberikan pengajaran, khususnya membutuhkan kemampuan mengajukan pertanyaan tingkat tinggi yang bisa menggali serta mengungkapkan nilai yang terdapat pada diri peserta didik. (4) Membutuhkan kreativitas pendidik dalam memakai media yang ada di lingkungan, khususnya yang faktual dan aktual sehingga dekat dengan hidup keseharian peserta didik.

Berdasarkan penjabaran sebelumnya, peneliti mengambil kesimpulan bahwa model pembelajaran VCT sangat sesuai untuk diaplikasikan pada mata pelajaran PKn demi mencapai target penanaman ataupun pembentukan sikap dan nilai dalam diri peserta didik sebab bisa memberi pengalaman belajar dalam kehidupan. Akan tetapi, pendidik juga harus bisa mengoptimalkan kreativitas dan kemampuannya ketika memakai media di lingkungan peserta didiknya.

\section{KESIMPULAN}

Pendidikan sekolah dasar merupakan awal dari jenjang pengambilan keputusan berbasis nilai-nilai ke garis terdepan yaitu penanaman dan pengembangan kesadaran nilai moral. Dalam pembelajaran model VCT (Value Clarification Technique) pada mata pelajaran PKn bisa membantu peningkatan kesadaran nilai moral peserta didik sekolah dasar. Pembelajaran PKn (pendidikan kewarganegaraan) menjadi bidang dimana siswa secara khusus disebut sebagai wadah untuk membantu siswa dalam klarifikasi nilai moral. Siswa melakukan berbagai aktivitas pembelajaran yang bermanfaat untuk belajar tentang nilai moral, dan memiliki tugas khusus yang membantu dalam mengklarifikasi nilai. Kesadaran nilai moral sangat penting untuk menjadikan sebagai warga negara yang baik, bisa bermasyarakat, saling menghargai, saling menolong, bentuk menjadikan siswa yang bermoral dan baik dalam menghadapi kehidupan sosial yang akan dibutuhkan dan selalu berkembang untuk saat ini serta masa mendatang. Dengan demikian, pendidik bisa melakukan implementasi pendekatan klarifikasi nilai menjadi metode alternatif untuk pengajaran moral di sekolah dalam pembelajaran PKn.

\section{UCAPAN TERIMA KASIH}

Puji syukur penulis panjatkan atas kehadirat Allah SWT, yang sudah memberikan limpahan rahmat sehingga penulis bisa merampungkan artikel yang berjudul Implikasi Model Pembelajaran VCT (Value Clarification Technique) dalam Meningkatkan Kesadaran Nilai Moral pada Pembelajaran PKn di SD ini. Tak lupa pula terima kasih penulis sampaikan kepada seluruh pihak yang selalu senantiasa memberi motivasi serta semangat pada penulis.

\section{DAFTAR PUSTAKA}

Adisusilo, S. 2013. Pembelajaran Nilai Karakter Konstruksi Dan Vct Sebagai Inovasi Pendekatan Pembelajaran Afektif. Depok: Pt Rajagrafindo Persada.

Agustin, N., \& Hamid, S. I. 2017. "Pengaruh Model Pembelajaran Vet Terhadap Penalaran Moral Siswa Dalam Pembelajaran Pkn Sd.” Jurnal Moral Kemasyarakatan 2(1): 59-74. 
5057 Implikasi Model Pembelajaran VCT (Value Clarification Technique) dalam Meningkatkan Kesadaran Nilai Moral pada Pembelajaran PKn di SD - Farah Sabilla Febriany, Hani Risdiany, Dinie Anggraeni Dewi, Yayang Furi Furnamasari

DOI : https://doi.org/10.31004/basicedu.v5i6.1589

Ananda, Rizki. 2014. "Analisis Implementasi Pendekatan Saintifik Dalam Pembelajaran Pendidikan Kewarganegaraan: Studi Kasus Di Kelas Iv Sd Islam Ibnu Sina Kabupaten Bandung Dan Kelas Iii Sd Laboratorium Upi Cibiru." Universitas Pendidikan Indonesia.

. 2017. "Penggunaan Media Audio Visual Untuk Meningkatkan Hasil Belajar Pendidikan Kewarganegaraan Siswa Kelas Iv Sdn 016 Bangkinang Kota.” Jurnal Basicedu 1(1): 21-30.

. 2018. "Peningkatan Pembelajaran Pkn Dengan Penerapan Metode Role-Playing Siswa Kelas Ii Sdn 003 Bangkinang Kota." Jurnal Basicedu 2(1): 33-42.

Ananda, Rizki, Fadhilaturrahmi Fadhilaturrahmi, And Imam Hanafi. 2021. "Dampak Pandemi Covid-19 Terhadap Pembelajaran Tematik Di Sekolah Dasar.” Jurnal Basicedu 5(3): 1689-94.

Atika Mayasari. 2018. "Dampak Value Clarification Technique Terhadap Pemahaman Moral Siswa Di Kelas 1 Sd." Universitas Muhammadiyah Surakarta.

Bee Piang Tan, Noor Banu Mahadir Naidu, Zuraini Jamil. 2018. "Nilai-Nilai Moral Dan Warga Negara Yang Baik Dalam Masyarakat Multi-Etnis: Analisis Isi Buku Teks Pendidikan Moral Di Malaysia." Jurnal Penelitian Ilmu Sosial 42(2): 119-34.

Cokelat, G. 2007. M. W. E. P. Dan P. P. J. I. P. P. 2007. "Menjadikan Warga Etnis: Politik Dan Praktik Pendidikan." Jurnal Internasional Pengembangan Pendidikan.

Habibah. 2007. Metode Pengembangan Moral Anak Pra Sekolah. Yogyakarta: Fip Uny.

Kirschenbaum, H. 2013. Klarifikasi Nilai Dalam Konseling Dan Psikoterapi: Strategi Praktis Untuk Pengaturan Individu Dan Grup. Pers Universitas Oxford.

Komalisari, K. 2010. "Pembelajaran Kontekstual: Konsep Dan Aplikasi. Refika Aditama. Muhtadi, A. (2007). Teknik Dan Pendekatan Penanaman Nilai Dalam Proses Pembelajaran Di Sekolah.” Majalah Ilmiah Pembelajaran 3(1): 60-69.

Nila Vitasari. 2015. 13 Https://Eprints.Uny.Ac.Id/24213/ "Pelaksanaan Penanaman Moral Siswa Di Sekolah Dasar Muhammadiyah Wirobrajan Iii, Yogyakarta Tahun Ajaran 2014/2015." Universitas Negeri Yogyakarta.

Pratomo, W. (N.D.). Memahami Pendekatan Dan Habituasi Pkn Sebagai Pendidikan Nilai Dan Moral Bagi Guru Di Sekolah Dasar.

Riza, U. 2021. "Pengembangan E-Modul Pembelajaran Sejarah Berbasis Teknik Klarifikasi Nilai (Vct)." Jurnal Pendidikan Sejarah Universitas Jember.

Rodiyana, R. 2019. "Media Publikasi Pada Bidang Pendidikan Dasar.” Jurnal Cakrawala Pendas 5(1): 8-18.

Solihatin, E. 2012. Strategi Pembelajaran Ppkn. Bumi Aksara. Suparno, P. (2002). Pendidikan Budi Pekerti Di Sekolah, Suatu Tinjauan Umum. Yogyakarta: Kanisius.

Suparno, Paul. 2002. Pendidikan Budi Pekerti Di Sekolah. Yogyakarta: Kanisius.

Taniredja, T., Faridli, E. M., \& Harimanto, S. 2015. Model Model Pembelajaran Inovatif Dan Efektif. Alfabeta.

Taniredja, T. Dkk. 2012. Model-Model Pembelajaran Inovatif. Alfabeta.

Taniredja, Tukiran Dkk. 2012. Model-Model Pembelajaran Inovatif. Bandung: Alfabeta.

Wuryandani, W. 2010. "Peranan Keluarga Dalam Menanamkan Nilai Moral Pada Anak Usia Dini.” Diklus 14(1): 76-85. 